\title{
Comparative electrochemical treatments of two chlorinated aliphatic hydrocarbons. Time course of the main reaction by-products
}

\author{
Serena Randazzo ${ }^{\mathrm{a}, \mathrm{b}}$, Onofrio Scialdone ${ }^{\mathrm{b}}$, Enric Brillas ${ }^{\mathrm{a}}$, Ignasi Sirés ${ }^{\mathrm{a}, *}$ \\ a Laboratori d'Electroquímica dels Materials i del Medi Ambient, Departament de Química Física, Facultat de Química, Universitat de Barcelona, \\ Martí i Franquès 1-11, 08028 Barcelona, Spain \\ ${ }^{\mathrm{b}}$ Dipartimento di Ingegneria Chimica, Gestionale, Informatica e Meccanica, Università di Palermo, Viale delle Scienze, 90128 Palermo, Italy
}

\section{A R T I C L E I N F O}

\section{Article history:}

Received 7 April 2011

Received in revised form 10 June 2011

Accepted 27 June 2011

Available online 1 July 2011

\section{Keywords:}

1,2-Dichloroethane

Electrochemical water treatment

technologies

Electro-Fenton

Organochlorinated pollutants

Reaction pathway

1,1,2,2-Tetrachloroethane

\begin{abstract}
A B S T R A C T
Acidic aqueous solutions of the chlorinated aliphatic hydrocarbons 1,2-dichloroethane (DCA) and 1,1,2,2tetrachloroethane (TCA) have been treated by the electro-Fenton (EF) process. Bulk electrolyses were performed at constant current using a BDD anode and an air diffusion cathode able to generate $\mathrm{H}_{2} \mathrm{O}_{2}$ in situ, which reacts with added $\mathrm{Fe}^{2+}$ to yield $\bullet \mathrm{OH}$ from Fenton's reaction. At $300 \mathrm{~mA}$, almost total mineralization was achieved at $420 \mathrm{~min}$ for solutions containing $4 \mathrm{mM}$ of either DCA or TCA. Comparative treatments without $\mathrm{Fe}^{2+}$ (anodic oxidation) or with a Pt anode led to a poorer mineralization. The better performance of the EF process with BDD is explained by the synergistic action of the oxidizing radicals, $\mathrm{BDD}\left(\bullet^{\bullet} \mathrm{OH}\right)$ at the anode surface and $\cdot \mathrm{OH}$ in the bulk, and the minimization of diffusional limitations. The decay of the initial pollutant accomplished with pseudo first-order kinetics. Chloroacetic and dichloroacetic acids were the major by-products during the degradation of DCA and TCA, respectively. Acetic, oxalic and formic acids were also identified. The proposed reaction pathways include oxidative and reductive (cathodic) dechlorination steps. Chlorine was released as $\mathrm{Cl}^{-}$, being further oxidized to $\mathrm{ClO}_{3}{ }^{-}$and, mostly, to $\mathrm{ClO}_{4}{ }^{-}$, due to the action of the largely generated $\operatorname{BDD}(\bullet \mathrm{OH})$ and $\bullet \mathrm{OH}$.
\end{abstract}

(C) 2011 Elsevier B.V. All rights reserved.

\section{Introduction}

The nowadays society finds it difficult to ensure the clean water supply because domestic, agricultural and industrial activities are responsible for introducing refractory organic pollutants into the water streams. Major attention is paid to contaminants with an aromatic structure because they tend to be more toxic than their aliphatic counterparts. However, serious concerns arise from the presence of chlorinated aliphatic hydrocarbons in waters. These compounds conjugate toxicity with high chemical stability, bioaccumulation and long-range diffusivity [1]. Chloroethanes are particularly ubiquitous in the industry and in household products, and their entry to the environment may entail potential risks for the living beings [2]. At present, the US Environmental Protection Agency is carrying out the Endocrine Disruptor Screening Program (EDSP), where 1,2-dichloroethane (DCA) and 1,1,2,2-tetrachloroethane (TCA) are considered as priorities for their potential effects on the endocrine system. DCA is also found in the list of priority substances drawn up by the European Commission [3].

\footnotetext{
* Corresponding author. Tel.: +34 934021223; fax: +34 934021231.

E-mail address: i.sires@ub.edu (I. Sirés).
}

To avoid the release of chloroethanes into the aqueous environment, powerful water treatment technologies such as the advanced oxidation processes (AOPs) must be applied in the wastewater treatment facilities. AOPs are based on the action of the $\cdot \mathrm{OH}$ generated in situ to oxidize the biorecalcitrant organic matter $[4,5]$. Among them, electrochemical AOPs (EAOPs) such as anodic oxidation (AO) and electro-Fenton (EF) processes have gained much interest for the removal of organic compounds due to their outstanding technical characteristics [6-9]. Cañizares et al. [10-12] showed that the electrochemical degradation of organic pollutants using boron-doped diamond (BDD) anodes is more efficient than ozonation and Fenton oxidation, yielding higher removals at a competitive cost. In AO, the destruction of pollutants is mediated by hydroxyl radicals generated at the anode surface from water oxidation and its effectiveness depends dramatically on the anode material; BDD [13-23] and $\mathrm{PbO}_{2}$ [17-19,24,25] have been widely employed for the destruction of dyes $[18,20,21,25]$, pesticides [13-15,24,25], pharmaceutical residues [22,23] and industrial pollutants $[16,19]$. They exhibit much higher performance compared to classical anode materials due to the high oxidation ability of their physisorbed radicals $\left(\mathrm{BDD}(\bullet \mathrm{OH})\right.$ and $\left.\mathrm{PbO}_{2}(\bullet \mathrm{OH})\right)[26,27]$. BDD is usually preferred because of its greater chemical and mechanical stability and higher current efficiency [28]. The interest on the EF process has also been growing [8]. In this EAOP, large amounts of - $\mathrm{OH}$ are produced in the bulk at acidic $\mathrm{pH}$ from Fenton's reaction 
between cathodically electrogenerated $\mathrm{H}_{2} \mathrm{O}_{2}$ and added $\mathrm{Fe}^{2+}$. The continuous electrogeneration of $\mathrm{H}_{2} \mathrm{O}_{2}$ enhances the efficacy and the environmental compatibility compared to Fenton oxidation [29]. The regeneration of $\mathrm{Fe}^{2+}$ from cathodic reduction of $\mathrm{Fe}^{3+}$ is also an advantage in EF process [8]. EF has also been applied to the degradation of dyes [25,30-36], pesticides [37,38], pharmaceutical residues [39-43] and industrial pollutants [44,45] at bench- and pilot-scale trials. All the reactions involved in the complex mechanisms of $\mathrm{AO}$ and $\mathrm{EF}$ have been thoroughly reviewed elsewhere [8,9].

There exist several works on the degradation of chlorinated aliphatic hydrocarbons by AOPs, although only a few focus on chloroethanes. Trichloroethylene, tetrachloroethylene and DCA were treated with Fenton's reagent [46-48], which for example led to $100 \%$ degradation of DCA but with only $78 \%$ total organic carbon (TOC) removal [48]. Based on these positive results, hybrid technologies that involve the Fenton's process, $\mathrm{TiO}_{2}$ photocatalysis and/or $\mathrm{O}_{3}$ have been proposed for the removal of these pollutants [49-53]. Regarding the electrochemical treatments, several reduction and oxidation alternatives have been tested for many organic halides, as recently reviewed by Rondinini and Vertova [1]. Electroreduction with a silver cathode yielded high abatements (>90\%) for DCA and TCA [54]. However, this method mainly allows the efficient removal of the halogen(s) group(s), often ending in stable, toxic by-products $[1,54]$. Conversely, complete mineralization may be achieved with the alternative use of EAOPs. Thus, the AO of DCA gave high dissolved organic carbon (DOC) abatement with much higher current efficiencies using BDD than stainless steel, Pt, $\mathrm{Au}$, Ebonex, stainless, $\mathrm{Ti} / \mathrm{IrO}_{2}-\mathrm{Ta}_{2} \mathrm{O}_{5}$ and $\mathrm{PbO}_{2}$ anodes [55,56]. More recently, some of us proposed the coupling of AO with a BDD anode and electroreduction with a silver cathode for the treatment of DCA and TCA, thus taking advantage of the simultaneous cathodic and anodic reactions [57].

This article reports the degradation of acidic aqueous solutions of DCA and TCA under EF conditions, which benefits from the synergistic oxidation of hydroxyl radicals at the anode surface $\left(\mathrm{BDD}\left(\bullet^{\bullet} \mathrm{OH}\right)\right)$ and in the bulk $\left({ }^{\bullet} \mathrm{OH}\right)$. In contrast to all previous studies reporting the electrochemical treatment of chloroethanes at the electrode surfaces, the present work stresses the role of hydroxyl radicals co-generated in the bulk, aiming to minimize the usual diffusional limitations. Bulk electrolyses were performed at constant current with an air diffusion electrode (ADE) as the cathode to produce $\mathrm{H}_{2} \mathrm{O}_{2}$ and a BDD anode. The effect of various experimental parameters on the mineralization of single and multicomponent solutions was examined. The chromatographic identification and evolution of the main accumulated organic by-products allowed the proposal of original reaction pathways for DCA and TCA. In addition, the treatment of solutions containing a high concentration of initial $\mathrm{Cl}$ as DCA and TCA allowed the identification of the chlorinated species generated. Previous studies hypothesized that the low level of $\mathrm{Cl}^{-}$in the solutions electrolyzed with a BDD anode were due to its oxidation to free chlorine $\left(\mathrm{Cl}_{2}\right)$ [58-60]. Other authors showed the additional generation of chlorinated oxoanions such as $\mathrm{ClO}_{2}{ }^{-}$and $\mathrm{ClO}_{3}{ }^{-}$when electrolyzing chloride salts [61,62], even suggesting the total transformation into $\mathrm{ClO}_{4}{ }^{-}[28,63]$.

\section{Experimental}

\subsection{Chemicals}

DCA and TCA were reagent grade from Acros Organics ( $\geq 99 \%$ ). Carboxylic acids used in high-performance liquid chromatography (HPLC) analyses and chlorinated inorganic salts used for ion chromatography (IC) were either reagent or analytical grade $(\geq 98 \%)$ from Merck, Acros Organics, Fluka and Panreac. Sulfuric acid, anhydrous sodium sulfate and heptahydrated ferrous sulfate were analytical grade from Fluka and Merck. All solutions were prepared with ultra-pure water from a Millipore Milli-Q system with resistivity $>18 \mathrm{M} \Omega \mathrm{cm}$.

\subsection{Instruments and analytical procedures}

Constant current electrolyses were performed with an AMEL 2053 potentiostat/galvanostat. The solution $\mathrm{pH}$ was measured with a Crison GLP 22 pH-meter. Colourimetric measurements were made with a Unicam UV4 Prisma double-beam UV/Vis spectrometer thermostated at $20^{\circ} \mathrm{C}$. The concentration of $\mathrm{H}_{2} \mathrm{O}_{2}$ was determined from the light absorption of the $\mathrm{Ti}(\mathrm{IV})-\mathrm{H}_{2} \mathrm{O}_{2}$ coloured complex at $\lambda=408 \mathrm{~nm}$. The mineralization of the solutions was assessed from the decay of their DOC, which was determined with $\pm 2 \%$ accuracy on a Shimadzu VCSN TOC analyzer.

The decay of the concentration of DCA and TCA was followed by gas chromatography/mass spectrometry (GC/MS) using a Thermo Scientific TRACE GC Ultra gas chromatograph equipped with a Thermo Scientific TrisPlus autosampler in headspace mode and a DB-624 (60 m $\times 0.32 \mathrm{~mm}$ (i.d.) and $1.8 \mu \mathrm{m}$ film thickness) capillary column from Agilent Technologies, coupled with a Thermo Scientific DSQII quadrupole mass spectrometer. The temperature ramp was $60^{\circ} \mathrm{C}$ for $2 \mathrm{~min}, 8.0^{\circ} \mathrm{C} \mathrm{min}^{-1}$ up to $220^{\circ} \mathrm{C}$ and hold time $5 \mathrm{~min}$, and the temperature of the source was $200^{\circ} \mathrm{C}$. The identification was performed through comparison with pure standards. Isopropanol was employed as internal standard for quantification.

The time course of the carboxylic acid intermediates was followed by ion-exclusion HPLC using a Waters 600 chromatograph fitted with a Bio-Rad Aminex HPX $87 \mathrm{H}, 300 \mathrm{~mm} \times 7.8 \mathrm{~mm}$ (i.d.), column at $35^{\circ} \mathrm{C}$, and coupled with a Waters 996 photodiode array detector selected at $\lambda=210 \mathrm{~nm}$. A $4 \mathrm{mM} \mathrm{H}_{2} \mathrm{SO}_{4}$ solution was eluted at $0.6 \mathrm{~mL} \mathrm{~min}^{-1}$ as the mobile phase. The chlorinated inorganic anions were determined by IC using a Shimadzu 10 Avp HPLC coupled with a Shimadzu CDD 10 Avp conductivity detector. The liquid chromatograph was fitted with a Shim-Pack IC-A1S, $100 \mathrm{~mm} \times 4.6 \mathrm{~mm}$ (i.d.), anion column at $40^{\circ} \mathrm{C}$, and the mobile phase was a solution with $2.4 \mathrm{mM}$ tris(hydroxymethyl)aminomethane and $2.5 \mathrm{mM}$ phthalic acid of $\mathrm{pH}$ 4.0 at $1.0 \mathrm{~mL} \mathrm{~min}^{-1}$. All species were identified by comparison of their retention times $\left(t_{\mathrm{r}}\right)$ with those of pure standards.

\subsection{Electrolytic systems}

The electrolyses were conducted in a cylindrical, undivided, water-jacketed glass cell containing $130 \mathrm{~mL}$ of solution. A scheme of the electrolytic system used is shown in Fig. 1. The headspace above the solution was kept to a minimum to reduce the amount of possible volatile organic compounds (VOCs) in the gas phase. In addition, a condenser with circulating water at $10 \pm 1^{\circ} \mathrm{C}$ was used to prevent loss of VOCs. A copper cooling-finger was immersed in a water bath to reach the required temperature. The anode was usually a $3 \mathrm{~cm}^{2}$ BDD film (1300 ppm of B, $1.33 \mu \mathrm{m}$ thickness) deposited on single crystal p-type $\mathrm{Si}(100)$ wafers supplied by Adamant Technologies. Comparative experiments were performed using a $3 \mathrm{~cm}^{2}$ Pt foil (99.99\% purity) from SEMPSA. The cathode was always a $3 \mathrm{~cm}^{2}$ carbon-PTFE ADE from E-TEK, which was fed with $0.35 \mathrm{~L} \mathrm{~min}^{-1}$ of compressed air to electrogenerate $\mathrm{H}_{2} \mathrm{O}_{2}$ from the two-electron reduction of $\mathrm{O}_{2}$. The interelectrode gap was $1 \mathrm{~cm}$.

The behaviour of single component solutions was assessed with 2 or $4 \mathrm{mM}$ DCA or TCA and $0.035 \mathrm{M} \mathrm{Na}_{2} \mathrm{SO}_{4}$ at pH 3.0 and $10 \pm 1{ }^{\circ} \mathrm{C}$ under a constant current between 100 and $450 \mathrm{~mA}$. The EF treatments were performed using $0.5 \mathrm{mM} \mathrm{Fe}^{2+}$ as catalyst. Comparative $\mathrm{AO}$ experiments were made without $\mathrm{Fe}^{2+}$ and feeding the cathode with pure $\mathrm{N}_{2}$. Multicomponent solutions containing both DCA and TCA were also degraded. All trials were performed under vigorous stirring with a magnetic bar to ensure a good mixing and repro- 


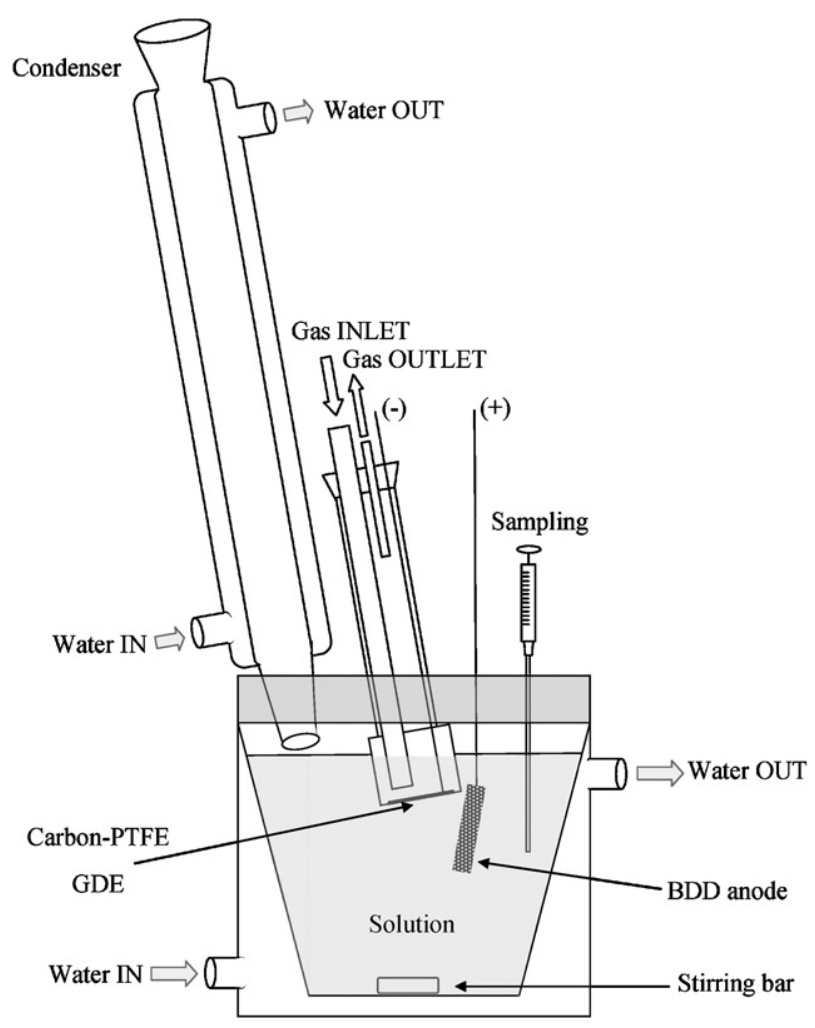

Fig. 1. Scheme of the experimental setup.

ducible mass transport conditions. The $\mathrm{pH} 3.0$ was selected because it is the optimum value for Fenton's reaction [8].

\section{Results and discussion}

\subsection{Mineralization of DCA and TCA solutions by EAOPs}

Since the EF treatment is based on the $\mathrm{H}_{2} \mathrm{O}_{2}$ electrogeneration for the $\bullet \mathrm{OH}$ production from Fenton's reaction, the first task was to ensure that the ADE cathode was able to produce enough $\mathrm{H}_{2} \mathrm{O}_{2}$ for the degradation of the organic matter. Fig. 2 shows the time course of this species during the electrolysis of several solutions with $0.035 \mathrm{M} \mathrm{Na}_{2} \mathrm{SO}_{4}$ at $\mathrm{pH} 3.0$ and $10^{\circ} \mathrm{C}$ in the BDD/ADE cell at $300 \mathrm{~mA}$ for $480 \mathrm{~min}$. In the absence of $\mathrm{Fe}^{2+}$ and organics (AO conditions), $\mathrm{H}_{2} \mathrm{O}_{2}$ was gradually accumulated during the first $240 \mathrm{~min}$,

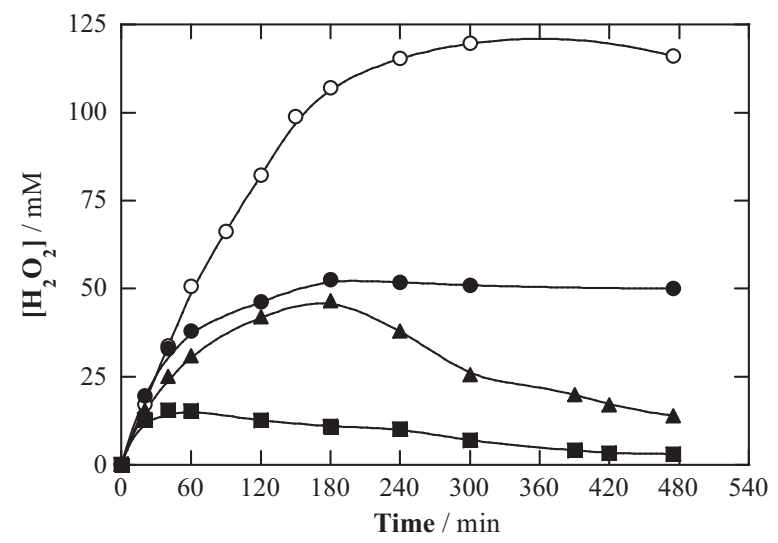

Fig. 2. Time course of accumulated $\mathrm{H}_{2} \mathrm{O}_{2}$ during the electrolysis of $130 \mathrm{~mL}$ of $0.035 \mathrm{M}$ $\mathrm{Na}_{2} \mathrm{SO}_{4}$ solutions at $\mathrm{pH} 3.0,300 \mathrm{~mA}$ and $10^{\circ} \mathrm{C}$ using a BDD/ADE cell. $\mathrm{Fe}^{2+}$ concentration: ( $\bigcirc) 0 \mathrm{mM}$ and $(\bullet, \mathbf{\square}, \mathbf{\Lambda}) 0.5 \mathrm{mM} ; 1,2$-dichloroethane (DCA) concentration: $(\bigcirc$, ๑) $0 \mathrm{mM},(\boldsymbol{\Delta}) 2 \mathrm{mM}$ and (ם) $4 \mathrm{mM}$.

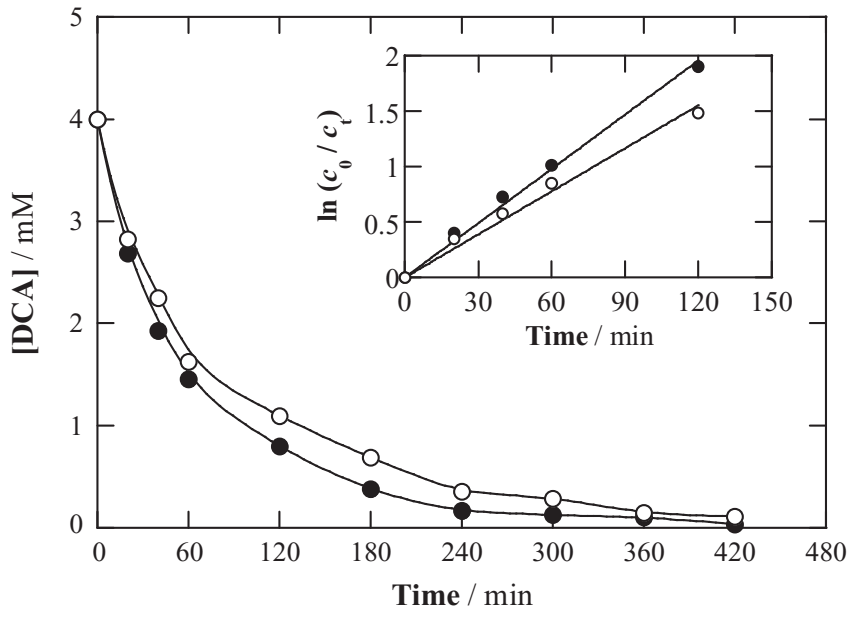

Fig. 3. DCA concentration vs electrolysis time during the degradation of $130 \mathrm{~mL}$ of $4 \mathrm{mM}$ DCA in $0.035 \mathrm{M} \mathrm{Na}_{2} \mathrm{SO}_{4}$ at $300 \mathrm{~mA}, \mathrm{pH} 3.0$ and $10^{\circ} \mathrm{C}$ using a BDD/ADE cell by $(\bigcirc)$ anodic oxidation (AO) with $\mathrm{N}_{2}$ supply to the cathode and (๑) electro-Fenton (EF) with $0.5 \mathrm{mM} \mathrm{Fe}{ }^{2+}$. The inset panel depicts the corresponding kinetic analysis assuming pseudo first-order reaction for DCA.

reaching a steady value of about $120 \mathrm{mM}$ once the rate of $\mathrm{H}_{2} \mathrm{O}_{2}$ formation at the cathode became equal to its destruction rate at the cathode, at the anode and in the bulk.

When $0.5 \mathrm{mM} \mathrm{Fe}^{2+}$ was added (EF conditions), the steady state $\mathrm{H}_{2} \mathrm{O}_{2}$ concentration decreased to about $50 \mathrm{mM}$ due to its rapid destruction mainly with $\mathrm{Fe}^{2+}$ through the classical Fenton's reaction yielding $\bullet \mathrm{OH}[8,9]$. Similar electrolyses carried out with $0.5 \mathrm{mM}$ $\mathrm{Fe}^{2+}$ and $2 \mathrm{mM}$ DCA yielded a lower maximum $\mathrm{H}_{2} \mathrm{O}_{2}$ concentration, which continuously decreased from $180 \mathrm{~min}$. This behaviour is accounted for by a higher consumption of ${ }^{\bullet} \mathrm{OH}$ for organic matter oxidation, which immediately enhances the $\mathrm{H}_{2} \mathrm{O}_{2}$ destruction by Fenton's reaction. The electrolysis of a $4 \mathrm{mM}$ DCA solution produced even much lower $\mathrm{H}_{2} \mathrm{O}_{2}$ accumulation due to the larger amounts of - $\mathrm{OH}$ involved in the oxidation of organic compounds, thus accelerating the Fenton's reaction. The same trends were observed using TCA solutions (data not shown).

GC/MS was used to study the decay of the DCA and TCA concentration with time. Blank experiments with addition of commercial $\mathrm{H}_{2} \mathrm{O}_{2}$, but without current, demonstrated that DCA and TCA solutions were not degraded by this oxidant, indicating that generated hydroxyl radicals were the main species able to degrade both chloroethanes in $\mathrm{AO}$ and $\mathrm{EF}$.

Fig. 3 shows the decay for $4 \mathrm{mM}$ DCA solutions in $0.035 \mathrm{M}$ $\mathrm{Na}_{2} \mathrm{SO}_{4}$ by $\mathrm{AO}$ (without $\mathrm{Fe}^{2+}$, with $\mathrm{N}_{2}$ supply to the cathode to prevent the $\mathrm{H}_{2} \mathrm{O}_{2}$ generation $)$ and $\mathrm{EF}\left(0.5 \mathrm{mM} \mathrm{Fe}^{2+}\right.$, with air supply to the cathode) using the same BDD/ADE cell at $300 \mathrm{~mA}$. A progressive destruction of DCA can be observed in AO by the main oxidative action of $\operatorname{BDD}\left(\bullet^{\bullet} \mathrm{OH}\right)$, remaining $3 \%$ at $420 \mathrm{~min}$. The quicker removal achieved in $\mathrm{EF}$, with total disappearance in $420 \mathrm{~min}$, confirms the higher oxidation power of this process. This can be explained by: (i) the higher concentration of hydroxyl radicals thanks to the simultaneity of two generation ways, $\operatorname{BDD}(\bullet \mathrm{OH})$ at the anode and - $\mathrm{OH}$ in the bulk, and (ii) the minimization of the diffusional limitations that are inherent to the electrode processes such as AO. The inset of Fig. 3 depicts the excellent linear correlations, with $R^{2}>0.99$, obtained assuming pseudo first-order reaction between DCA and generated hydroxyl radicals. The apparent rate constant $\left(k_{\mathrm{app}}\right)$ determined for the experiments without and with $\mathrm{Fe}^{2+}$ were 0.013 and $0.016 \mathrm{~min}^{-1}$, respectively, as expected for the quicker destruction in the EF process. A similar behaviour was found for TCA solutions (not shown). 


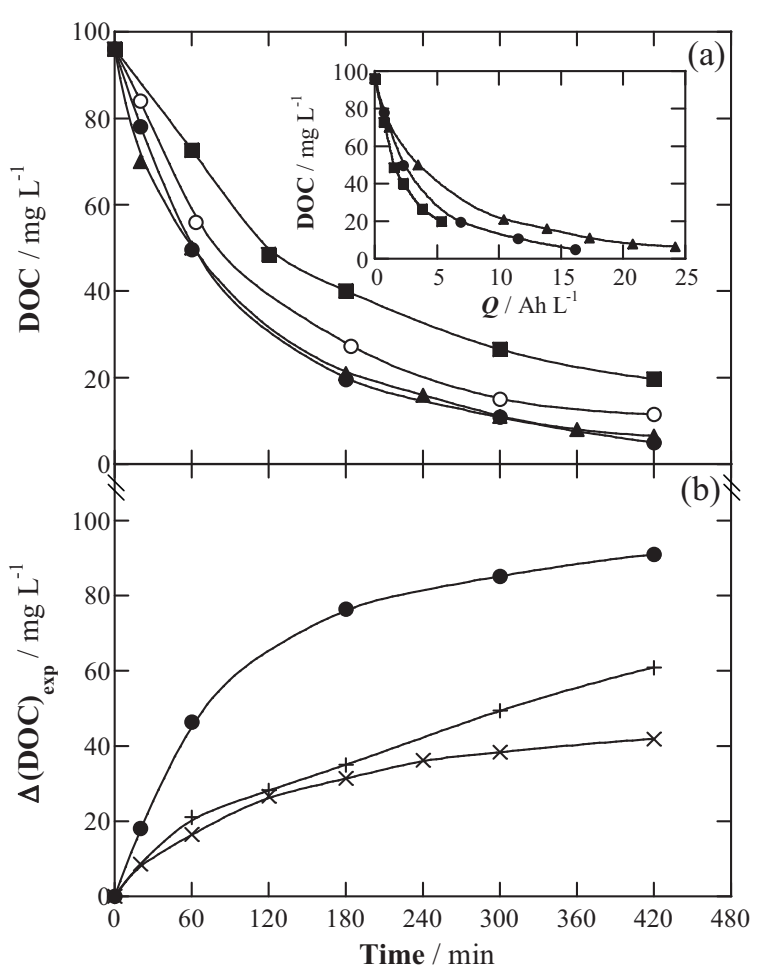

Fig. 4. (a) DOC abatement vs electrolysis time for treating $130 \mathrm{~mL}$ of $4 \mathrm{mM}$ DCA in $0.035 \mathrm{M} \mathrm{Na}_{2} \mathrm{SO}_{4}$ at $\mathrm{pH} 3.0$ and $10^{\circ} \mathrm{C}$ using a BDD/ADE cell. ( $\left.\bigcirc\right) \mathrm{AO}$ and $(\bullet, \mathbf{\square}, \mathbf{\Delta}) \mathrm{EF}$ with $0.5 \mathrm{mM} \mathrm{Fe}{ }^{2+}$. Current: $(\mathbf{\square}) 100 \mathrm{~mA},(\bigcirc, \bullet) 300 \mathrm{~mA}$ and $(\boldsymbol{\Delta}) 450 \mathrm{~mA}$. The inset panel shows the DOC removal vs specific charge for the EF trials. (b) $\Delta$ (DOC) exp vs electrolysis time for the EF degradation of: (-) $4 \mathrm{mM}$ and $(x) 2 \mathrm{mM} \mathrm{DCA}$ in a BDD/ADE cell and (+) 4 mM DCA in a Pt/ADE cell. Current: $300 \mathrm{~mA}$.

Fig. 4(a) shows the effect of several operating parameters on the DOC decay for the above $4 \mathrm{mM}$ DCA $\left(96.0 \mathrm{mg} \mathrm{L}^{-1} \mathrm{DOC}\right)$ solutions using $\mathrm{AO}$ and EF. At $300 \mathrm{~mA}$, a slower degradation was achieved by AO, with $91 \%$ DOC removal at $420 \mathrm{~min}$, whereas almost total mineralization (>95\% DOC decay) was reached by EF. Such enhancement is consistent with the larger production of hydroxyl radicals at the anode and in the bulk. This coupling leads to a conspicuous increase of the treatment efficiency because both anodic and cathodic currents contribute to the destruction of the organic matter. In fact, even the participation of some electroreduction reactions cannot be discarded until the intermediates are analysed, although such reactions are expected to be much less significant compared to the $\operatorname{BDD}(\bullet \mathrm{OH}) / \bullet \mathrm{OH}$-mediated reactions. Fig. 4(a) also shows acceleration in DOC abatement with increasing current for the EF treatment. The degradation rate was much lower at $100 \mathrm{~mA}$ due to the lower production rate of $\bullet \mathrm{OH}$ and $\operatorname{BDD}(\cdot \mathrm{OH})$, only achieving $80 \%$ mineralization at the end of the electrolysis. The faster oxidation of $\mathrm{H}_{2} \mathrm{O}$, electrogeneration of $\mathrm{H}_{2} \mathrm{O}_{2}$ and cathodic regeneration of $\mathrm{Fe}^{2+}$ at $300 \mathrm{~mA}$ largely contributes to the significant acceleration of the degradation process. However, the enhancement obtained from 300 to $450 \mathrm{~mA}$ was not as remarkable as that produced from 100 to $300 \mathrm{~mA}$, suggesting a greater limitation by mass transport phenomena at high current, i.e., the oxidation rate becomes mainly controlled by the transport of oxygen and iron ions toward the cathode and organic compounds toward the anode. The inset panel of Fig. 4(a) shows that an increase in the applied current, from 100 to $450 \mathrm{~mA}$, causes higher specific charge consumption for attaining a given DOC value (i.e., a lower current efficiency). This is due to the increasing extent of the parasitic reactions such as $\mathrm{O}_{2}$ evolution, which do not invest the hydroxyl radicals to oxidize the organic matter, thereby leading to the progressive waste of the supplied current.

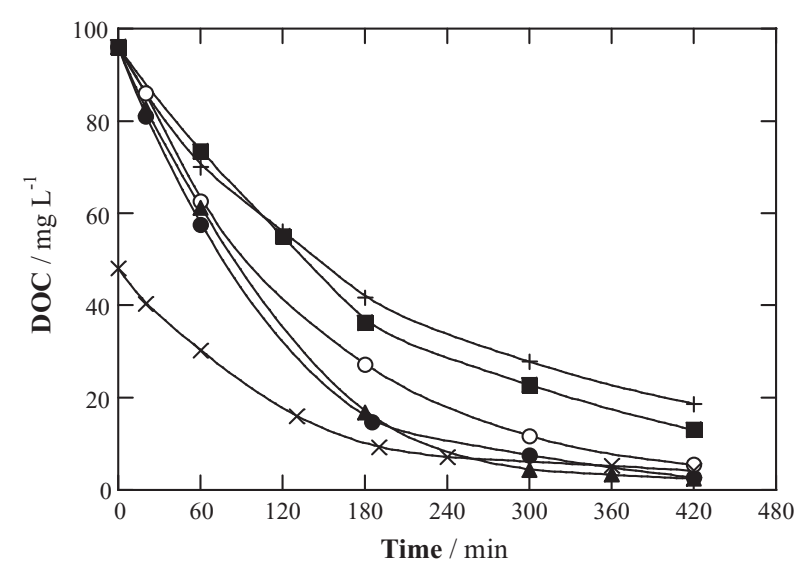

Fig. 5. DOC removal with electrolysis time for the treatment of $1,1,2,2$ tetrachloroethane (TCA) solutions under the same conditions of Fig. 4.

Fig. 4(b) presents the evolution of $\Delta(D O C)_{\exp }$ for the above EF degradation of $4 \mathrm{mM}$ DCA at $300 \mathrm{~mA}$ compared to $2 \mathrm{mM}$ DCA (48.0 $\mathrm{mg} \mathrm{L}^{-1}$ DOC). A larger amount of DOC was removed when treating $4 \mathrm{mM}$ DCA at any time and at the end of electrolysis, 42 and $91 \mathrm{mg} \mathrm{L}^{-1}$ of DOC were removed for 2 and $4 \mathrm{mM}$ DCA, respectively. This means that at a higher pollutant concentration the EF process proceeds very well; a smaller fraction of hydroxyl radicals is wasted in parasitic reactions (e.g., reactions between the radicals and $\mathrm{H}_{2} \mathrm{O}_{2}$ or iron species, as well as self-dimerisation to $\mathrm{H}_{2} \mathrm{O}_{2}$ ) because they interact with a larger number of organic molecules that are available. As a result, a more efficient process was obtained for $4 \mathrm{mM}$ DCA. Fig. 4(b) also depicts the comparison of the EF treatment of $4 \mathrm{mM} \mathrm{DCA}$ in the BDD/ADE and Pt/ADE cells at $300 \mathrm{~mA}$, with applied potentials of 28-30 and 20-22 V, respectively. As observed, the latter cell yielded a much poorer mineralization, with only $61 \%$ DOC removal at $420 \mathrm{~min}$. This confirms the importance of the oxidation process at the BDD anode, which becomes a fundamental synergistic contribution to the oxidation in the bulk.

Fig. 5 depicts the effect of the same operating parameters on the mineralization of similar TCA solutions using the BDD/ADE and Pt/ADE cells. The conclusions drawn are analogous to those of Fig. 4, although the degradation rate from 120 min becomes slightly higher than that of DCA, probably due to the formation of more easily oxidizable by-products. Thus, the solutions of $4 \mathrm{mM}$ TCA were completely mineralized by EF with BDD at 300 and $450 \mathrm{~mA}$, whereas AO with BDD and EF with Pt led to 94\% and 80\% DOC removal, respectively.

\subsection{Time course of the main reaction by-products}

GC/MS analysis of the above electrolyzed solutions did not show any other chloroalkane or chloroalkene as organic by-product. Since hydroxylated compounds are formed from $\operatorname{BDD}\left({ }^{\bullet} \mathrm{OH}\right) /{ }^{\bullet} \mathrm{OH}-$ mediated oxidation [8], the generated short-chain carboxylic acids were analyzed by ion-exclusion HPLC. Figs. 6 and 7 show the time course of acids detected during the treatment of DCA and TCA solutions under the conditions of Figs. 4 and 5, respectively. These by-products are always accumulated in the first stage of all treatments because their generation from the cleavage of the parent molecules, whose high initial concentration causes the consumption of most of the hydroxyl radicals, predominates over their destruction, and after reaching a maximum concentration they are progressively converted into other by-products and/or $\mathrm{CO}_{2}+\mathrm{H}_{2} \mathrm{O}$.

Four acids were formed for DCA: chloroacetic $\left(t_{\mathrm{r}}=14.7 \mathrm{~min}\right)$ and acetic $\left(t_{\mathrm{r}}=14.9 \mathrm{~min}\right)$ displayed two partially overlapped peaks in the chromatograms, whereas the peaks for oxalic $\left(t_{\mathrm{r}}=6.9 \mathrm{~min}\right)$ and formic $\left(t_{\mathrm{r}}=13.7 \mathrm{~min}\right)$ appeared isolated. Since the same calibra- 


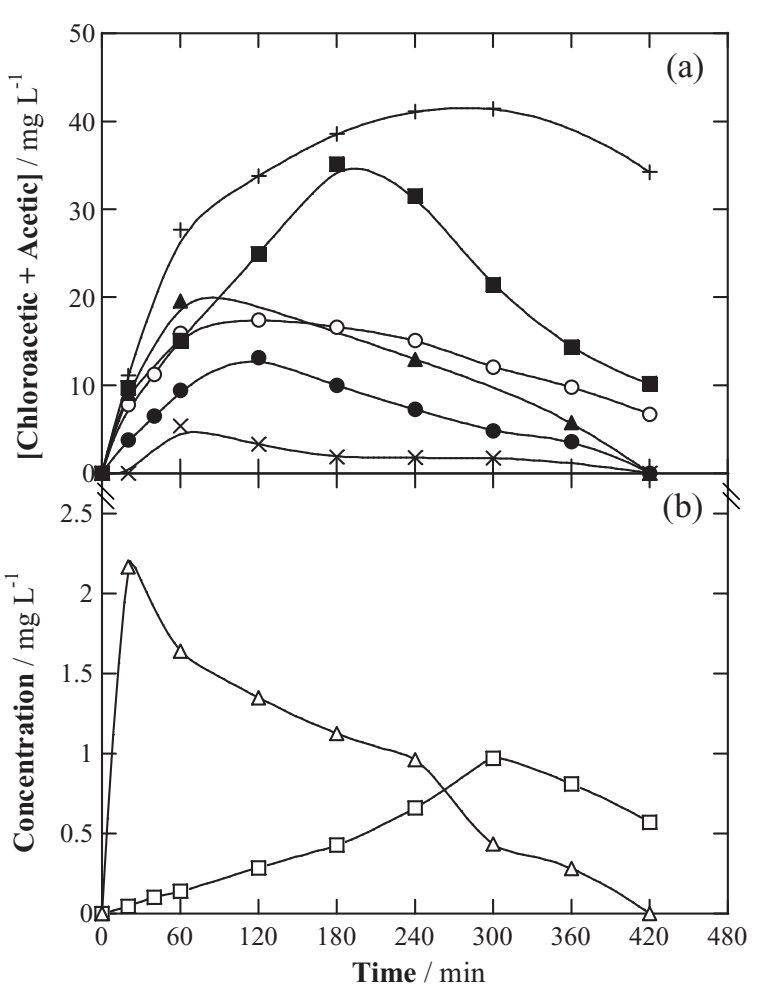

Fig. 6. (a) Time course of the concentration of chloroacetic + acetic acids detected during the mineralization of DCA under the conditions of Fig. 4. (b) Evolution of ( $\square$ ) oxalic and $(\triangle)$ formic acids during the EF degradation of $4 \mathrm{mM}$ DCA in a BDD/ADE cell at $300 \mathrm{~mA}$

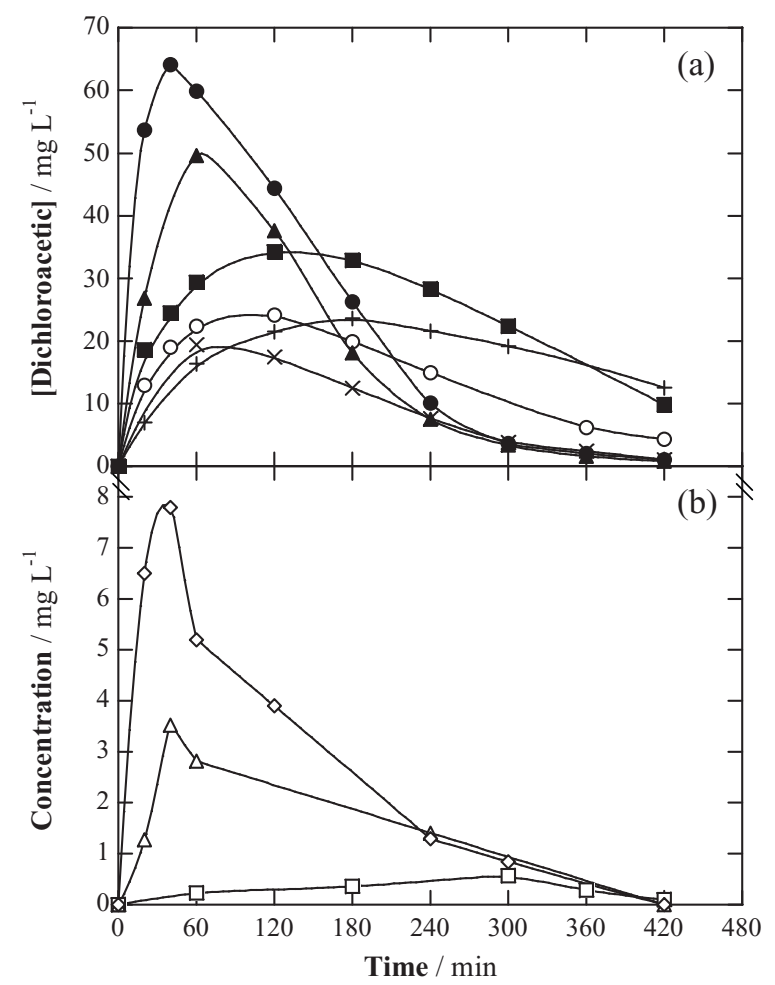

Fig. 7. (a) Evolution of dichloroacetic acid found during the degradation of TCA in the same conditions as in Fig. 5. (b) Time course of $(\diamond)$ chloroacetic + acetic, ( $\square$ ) oxalic and $(\triangle)$ formic acids during the EF treatment of 4 mM TCA in a BDD/ADE cell at $300 \mathrm{~mA}$. tion curve was found for chloroacetic and acetic acids, their sum is plotted in Fig. 6(a) for all experiments. As can be seen, EF with BDD at $300 \mathrm{~mA}$ leads to a maximum of $12 \mathrm{mg} \mathrm{L}^{-1}$ for this couple at $120 \mathrm{~min}$, whereupon they are rapidly destroyed up to reaching total destruction at $420 \mathrm{~min}$. Under these conditions, Fig. 6(b) shows lower concentrations for formic and oxalic acids, the latter being more persistent and remaining in the final electrolyzed solution. The importance of chloroacetic + acetic acids as the major by-products is confirmed for the trials at 100 and $450 \mathrm{~mA}$. Fig. 6(a) also depicts that they undergo higher accumulation in $\mathrm{AO}$ due to the absence of $\bullet \mathrm{OH}$ in the bulk, although EF with Pt yields the largest accumulation, reaching $>40 \mathrm{mg} \mathrm{L}^{-1}$ and being very slowly degraded. This corroborates the important role of hydroxyl radicals generated at the anode surface in the degradation process, $\operatorname{BDD}(\bullet \mathrm{OH})$ being much more active than $\operatorname{Pt}\left(\bullet^{\bullet} \mathrm{OH}\right)$ and $\bullet{ }^{\bullet} \mathrm{OH}$ in the bulk regarding the destruction of refractory compounds. Table 1 summarizes the DOC values determined at 60 and $420 \mathrm{~min}$ for all experiments, as well as the equivalent carbon content corresponding to the concentration found for carboxylic acids. It can be seen that the contribution of oxalic and formic acids to DOC is always much lower than that of chloroacetic + acetic acids.

In the case of TCA, the chromatograms displayed the peaks related to the same four acids plus dichloroacetic acid $\left(t_{\mathrm{r}}=8.1 \mathrm{~min}\right)$. As shown in Fig. 7(a) and in Table 1, dichloroacetic acid is always the major by-product, reaching $>60 \mathrm{mg} \mathrm{L}^{-1}$ in EF with BDD at $300 \mathrm{~mA}$. However, it is slightly less persistent than chloroacetic + acetic acids, since it undergoes some degradation in EF with Pt anode, but can be considered a refractory compound like chloroacetic shown above. This explains the higher DOC removal found for TCA (80\%) compared to DCA (61\%) in EF with the Pt/ADE cell at $300 \mathrm{~mA}$, as well as the slightly higher degradation rate of TCA solutions from 120 min of electrolysis (Figs. 4 and 5). Fig. 7(b) shows the trends of the other acids, which were totally removed.

It is important to notice that (mono)chloroacetic and dichloroacetic acid are typically formed during the disinfection of waters by chlorination, and their control is mandatory due to their potential carcinogenic and mutagenic effects [53]. Our findings for EF with Pt completely agree with others reported elsewhere for the Fenton treatment of these haloacetic acids [49,51,52]. For example, Nogueira et al. [51] and Lee et al. [52] found that dichloroacetic is

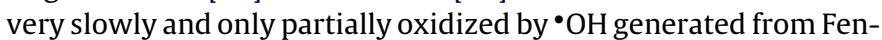
ton's reaction. Similarly, we have found that ${ }^{\bullet} \mathrm{OH}$ and $\mathrm{Pt}\left(\bullet^{\bullet} \mathrm{OH}\right)$ yield poor results for these acids and/or their simultaneously formed iron complexes. In contrast, it is very worth remarking that EF with BDD is able to completely destroy them, which confirms the importance of the synergistic action of $\operatorname{BDD}\left(\bullet^{\bullet} \mathrm{OH}\right)$. As will be discussed in Section 3.4, the $\operatorname{BDD}$ surface and/or the $\operatorname{BDD}(\bullet \mathrm{OH})$ are fundamental to allow the oxidation of other refractory species such as acetic acid and $\mathrm{Fe}(\mathrm{III})$-oxalate complexes [8].

Mixtures containing $2 \mathrm{mM}$ DCA and $2 \mathrm{mM}$ TCA were treated by $\mathrm{EF}$ with $\mathrm{BDD}$ at $300 \mathrm{~mA}$ to verify the decontamination of multicomponent solutions. As depicted in Fig. 8, the almost complete mineralization of solutions was achieved at $600 \mathrm{~min}$. The abovementioned five carboxylic acids were also identified in this experiment, being confirmed that dichloroacetic and chloroacetic + acetic are the major by-products, as shown in the inset panel of Fig. 8 and in Table 1.

\subsection{Fate of the chlorine contained in DCA and TCA}

Ion chromatography revealed the formation of $\mathrm{Cl}^{-}, \mathrm{ClO}_{3}{ }^{-}$and $\mathrm{ClO}_{4}{ }^{-}$ions during all electrolyses. The percentage of total $\mathrm{Cl}$ in these ions, along with their distribution, after 60 and $420 \mathrm{~min}$ of all experiments is summarized in Table 1. Fig. 9 exemplifies the evolution of these ions for the EF treatment of $4 \mathrm{mM}$ DCA or TCA with BDD at $300 \mathrm{~mA}$. Fig. 9(a) shows that chlorine is primarily released as $\mathrm{Cl}^{-}$ 
Table 1

Chlorine and carbon amounts contained in the chlorinated ions and carboxylic acids determined as the reaction by-products during the electrolyses of DCA, TCA, and DCA + TCA at pH 3.0 and $10{ }^{\circ} \mathrm{C}$.

\begin{tabular}{|c|c|c|c|c|c|c|c|c|c|c|c|c|c|c|}
\hline \multirow[t]{2}{*}{ Anode } & \multirow[t]{2}{*}{$\begin{array}{l}{[\mathrm{DCA}]} \\
(\mathrm{mM})\end{array}$} & \multirow[t]{2}{*}{$\begin{array}{l}{[\mathrm{TCA}]} \\
(\mathrm{mM})\end{array}$} & \multirow[t]{2}{*}{$\begin{array}{l}\mathrm{DOC} \\
\left(\mathrm{mg} \mathrm{L}^{-1}\right)\end{array}$} & \multirow[t]{2}{*}{$\begin{array}{l}{\left[\mathrm{Fe}^{2+}\right]} \\
(\mathrm{mM})\end{array}$} & \multirow[t]{2}{*}{$I(\mathrm{~mA})$} & \multirow[t]{2}{*}{$t(\min )$} & \multicolumn{3}{|c|}{$\mathrm{Cl}$ content from different sources $(\%)^{1,2}$} & \multicolumn{5}{|c|}{$\begin{array}{l}\text { Carbon content from different sources } \\
\left(\mathrm{mg} \mathrm{L}^{-1}\right)^{1,2,3,4,5}\end{array}$} \\
\hline & & & & & & & $\begin{array}{l}\text { Sum of chlorinated ions } \\
\left(\mathrm{Cl}^{-} ; \mathrm{ClO}_{3}^{-} ; \mathrm{ClO}_{4}^{-}\right)\end{array}$ & DCAA & MCAA & $\mathrm{DOC}$ & OXA & DCAA & FOR & $\mathrm{MCAA}+\mathrm{ACE}$ \\
\hline \multirow{22}{*}{ BDD } & \multirow{8}{*}{4} & \multirow[t]{2}{*}{-} & \multirow{8}{*}{96.0} & - & \multirow{4}{*}{300} & 60 & $50.9(34.6 ; 47.1 ; 18.3)$ & - & $0-2.1$ & 55.0 & 0.06 & - & 0.3 & $4.0-6.4$ \\
\hline & & & & \multirow{7}{*}{0.5} & & 420 & $92.6(5.8 ; 23.3 ; 70.9)$ & - & $0-0.9$ & 8.1 & 0.02 & - & 0.1 & $1.7-2.7$ \\
\hline & & \multirow[t]{2}{*}{-} & & & & 60 & $58.7(53.5 ; 35.8 ; 10.7)$ & - & $0-1.2$ & 49.6 & 0.04 & - & 0.4 & $2.4-3.8$ \\
\hline & & & & & & 420 & $97.0(2.9 ; 6.9 ; 90.2)$ & - & 0 & 5.0 & 0.2 & - & 0 & 0 \\
\hline & & \multirow[t]{2}{*}{-} & & & \multirow{2}{*}{100} & 60 & $29.8(72.4 ; 24.5 ; 3.1)$ & - & $0-2.0$ & 72.6 & 0.06 & - & 0.4 & $3.8-6.0$ \\
\hline & & & & & & 420 & $82.2(16.2 ; 52.8 ; 31.0)$ & - & $0-1.3$ & 19.7 & 0.2 & - & 0.2 & $2.6-4.1$ \\
\hline & & \multirow{2}{*}{-} & & & \multirow{2}{*}{450} & 60 & $52.4(44.3 ; 34.1 ; 21.6)$ & - & $0-2.6$ & 50.0 & 0.03 & - & 0.7 & $5.0-7.8$ \\
\hline & & & & & & 420 & $92.8(3.5 ; 10.1 ; 86.4)$ & - & 0 & 6.5 & 0.1 & - & 0 & 0 \\
\hline & \multirow[t]{2}{*}{2} & \multirow[t]{2}{*}{ - } & \multirow[t]{2}{*}{48.0} & & \multirow{2}{*}{300} & 60 & $50.0(45.0 ; 37.0 ; 18.0)$ & - & $0-1.4$ & 31.6 & 0.06 & - & 0 & $1.4-2.1$ \\
\hline & & & & & & 420 & $92.6(13.5 ; 21.7 ; 64.8)$ & - & 0 & 6.1 & 0.03 & - & 0 & 0 \\
\hline & \multirow[t]{2}{*}{ - } & \multirow[t]{8}{*}{4} & \multirow[t]{8}{*}{96.0} & - & \multirow[t]{4}{*}{300} & 60 & $28.9(47.0 ; 22.6 ; 30.4)$ & 2.2 & $0-0.4$ & 62.5 & 0.01 & 4.2 & 0.9 & $1.4-2.2$ \\
\hline & & & & & & 420 & $77.1(4.5 ; 7.2 ; 88.3)$ & 0.4 & $0-0.02$ & 5.5 & 0 & 0.8 & 0.4 & $0.08-0.1$ \\
\hline & - & & & 0.5 & & 60 & $38.1(55.3 ; 13.1 ; 31.6)$ & 5.8 & $0-0.3$ & 57.5 & 0.06 & 11.1 & 0.7 & $1.3-2.1$ \\
\hline & & & & & & 420 & $97.8(5.4 ; 8.3 ; 86.3)$ & 0.1 & 0 & 2.7 & 0.03 & 0.2 & 0 & 0 \\
\hline & - & & & & 100 & 60 & $23.1(69.0 ; 26.4 ; 4.61)$ & 2.8 & $0-0.02$ & 73.4 & 0.01 & 5.5 & 0.4 & $0.08-0.1$ \\
\hline & & & & & & 420 & $77.3(12.9 ; 38.5 ; 48.5)$ & 1.0 & $0-0.04$ & 13.1 & 0 & 1.8 & 0.2 & $0.2-0.3$ \\
\hline & - & & & & 450 & 60 & $53.3(43.5 ; 16.0 ; 40.5)$ & 4.8 & $0-0.2$ & 61.1 & 0.03 & 9.2 & 0.8 & $0.6-1.0$ \\
\hline & & & & & & 420 & $89.5(2.1 ; 4.2 ; 93.7)$ & 0.08 & 0 & 2.4 & 0 & 0.2 & 0 & 0 \\
\hline & - & 2 & 48.0 & & 300 & 60 & $41.4(41.3 ; 12.3 ; 46.4)$ & 3.8 & 0 & 30.2 & 0 & 3.6 & 1.0 & 0 \\
\hline & & & & & & 420 & $97.8(3.2 ; 4.5 ; 92.3)$ & 0.2 & 0 & 4.2 & 0 & 0.2 & 0 & 0 \\
\hline & 2 & 2 & 96.0 & 0.5 & 300 & 60 & $51.9(44.7 ; 33.5 ; 21.8)$ & 1.2 & $0-0.8$ & 65.2 & 0.03 & 1.8 & 0.4 & $2.3-3.6$ \\
\hline & & & & & & 420 & $91.8(2.8 ; 5.6 ; 91.6)$ & 0.1 & $0-0.1$ & 9.5 & 0 & 0.1 & 0.06 & $0.4-0.6$ \\
\hline Pt & 4 & - & 96.0 & 0.5 & 300 & 60 & $26.4(77.3 ; 12.9 ; 9.8)$ & - & $0-3.7$ & 74.9 & 0.01 & - & 1.4 & $7.0-11.1$ \\
\hline & & & & & & 420 & $71.2(21.0 ; 31.9 ; 47.0)$ & - & $0-4.5$ & 35.1 & 0.02 & - & 0.5 & $8.7-13.7$ \\
\hline & - & 4 & 96.0 & 0.5 & 300 & 60 & $25.2(70.6 ; 7.6 ; 21.8)$ & 1.6 & $0-0.1$ & 70.0 & 0.01 & 3.1 & 0.2 & $0.5-0.8$ \\
\hline & & & & & & 420 & $75.8(10.3 ; 16.4 ; 73.3)$ & 1.2 & $0-0.06$ & 18.7 & 0.01 & 2.3 & 0.2 & $0.3-0.4$ \\
\hline
\end{tabular}

Carboxylic acid: ${ }^{1}$ DCAA: Dichloroacetic; ${ }^{2}$ MCAA: Chloroacetic; ${ }^{3}$ OXA: Oxalic; ${ }^{4}$ FOR: Formic; ${ }^{5}$ ACE: Acetic. 


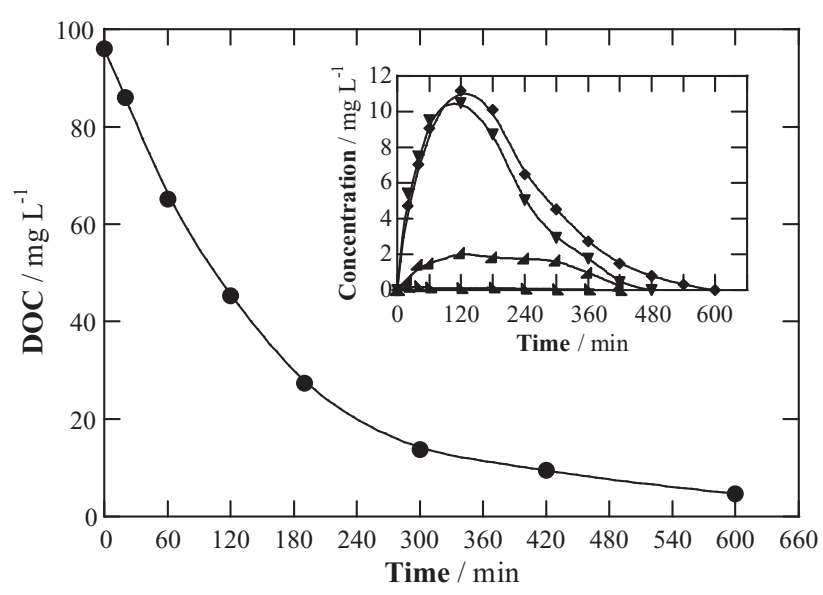

Fig. 8. DOC removal with electrolysis time for $130 \mathrm{~mL}$ of a solution with $2 \mathrm{mM}$ DCA and $2 \mathrm{mM} \mathrm{TCA}$ in $0.035 \mathrm{M} \mathrm{Na}_{2} \mathrm{SO}_{4}$ with $0.5 \mathrm{mM} \mathrm{Fe}^{2+}$ at pH $3.0,300 \mathrm{~mA}$ and $10^{\circ} \mathrm{C}$ by $\mathrm{EF}$ using a $\mathrm{BDD} / \mathrm{ADE}$ cell. The inset panel presents the concentration change for the short-chain carboxylic acids accumulated: $($ ) chloroacetic + acetic, ( $\mathbf{v})$ dichloroacetic, ( $)$ oxalic and ( $\boldsymbol{\Delta}$ ) formic.

from DCA, reaching a $31.4 \%$ of initial $\mathrm{Cl}$ at $60 \mathrm{~min}$. At this time, $\mathrm{ClO}_{3}{ }^{-}$ and $\mathrm{ClO}_{4}{ }^{-}$are present to a smaller extent $(27.3 \%$ of initial $\mathrm{Cl})$ and the remaining DCA and chloroacetic acid contain 36.6\% (Fig. 3) and $1.2 \%$ (Fig. 6(a)) of initial $\mathrm{Cl}$. With increasing electrolysis time, the amount of $\mathrm{Cl}^{-}$decreased, whereas that of $\mathrm{ClO}_{3}{ }^{-}$and $\mathrm{ClO}_{4}{ }^{-}$raised. At $420 \mathrm{~min}$, the chlorinated ions accounted for $97.0 \%$ of initial $\mathrm{Cl}$, being $87.5 \%$ as $\mathrm{ClO}_{4}{ }^{-}$, which is the least reactive oxidant among the chlorinated oxoanions due to its close shell structure. A similar behaviour can be observed in Fig. 9(b) for TCA, with $84.4 \%$ of initial $\mathrm{Cl}$ as $\mathrm{ClO}_{4}{ }^{-}$at $420 \mathrm{~min}$. Data of Table 1 confirm that higher currents favor the formation of $\mathrm{ClO}_{4}{ }^{-}$in $\mathrm{EF}$ with $\mathrm{BDD}$. Moreover, the use of BDD instead of Pt leads to a more pronounced accumulation of $\mathrm{ClO}_{4}^{-}$.

Our results agree with recent findings reporting the formation of $\mathrm{ClO}_{3}{ }^{-}$[61] and even its total transformation into $\mathrm{ClO}_{4}{ }^{-}$for the electrolysis of inorganic chloride salts with BDD [28,63]. It can be assumed that $\mathrm{Cl}^{-}$ions released during DCA and TCA degradation are oxidized at the BDD surface to active chlorine $\left(\mathrm{Cl}_{2}\right)$, being kinetically favored by the high overpotential of oxygen evolution at BDD [61]. Then, $\mathrm{Cl}_{2}$ reacts with water in the bulk to yield $\mathrm{HClO}$ that is consecutively transformed into $\mathrm{ClO}_{3}{ }^{-}$and $\mathrm{ClO}_{4}{ }^{-}$[60]. These latter reactions are expected to occur under the action of $\bullet \mathrm{OH}$ and $\operatorname{BDD}(\bullet \mathrm{OH})[28,61,63]$. The large amounts of both hydroxyl radicals produced in EF with BDD at high current can thus explain the almost total transformation into $\mathrm{ClO}_{4}{ }^{-}$. Similarly to what is reported for $\mathrm{BDD}$, the $\mathrm{AO}$ mechanism to form $\mathrm{ClO}_{4}{ }^{-}$at $\mathrm{Pt}$ involves the $\mathrm{Pt}\left({ }^{\bullet} \mathrm{OH}\right)$ [64]. Since this radical is much less active than $\operatorname{BDD}(\bullet \mathrm{OH})$, one can infer that the main contribution to the formation of $\mathrm{ClO}_{4}{ }^{-}$in $\mathrm{EF}$ with Pt comes from the oxidation by ${ }^{\bullet} \mathrm{OH}$ in the bulk.

\subsection{Proposed pathways for DCA and TCA mineralization}

From the identified by-products, the reaction pathways for the mineralization of DCA and TCA by EAOPs are proposed in Fig. 10(a) and (b), respectively. These sequences involve both reductive and oxidative dechlorination steps. Note that all the kinds of generated hydroxyl radicals are represented as ${ }^{\bullet} \mathrm{OH}$ and all the acids are given in their uncomplexed forms for the sake of simplicity, although their complexes with iron species are always present.

Pathway A in Fig. 10(a) involves the oxidative dechlorination of DCA to form chloroacetic acid, which is the major degradative route according to the concentrations determined for the different

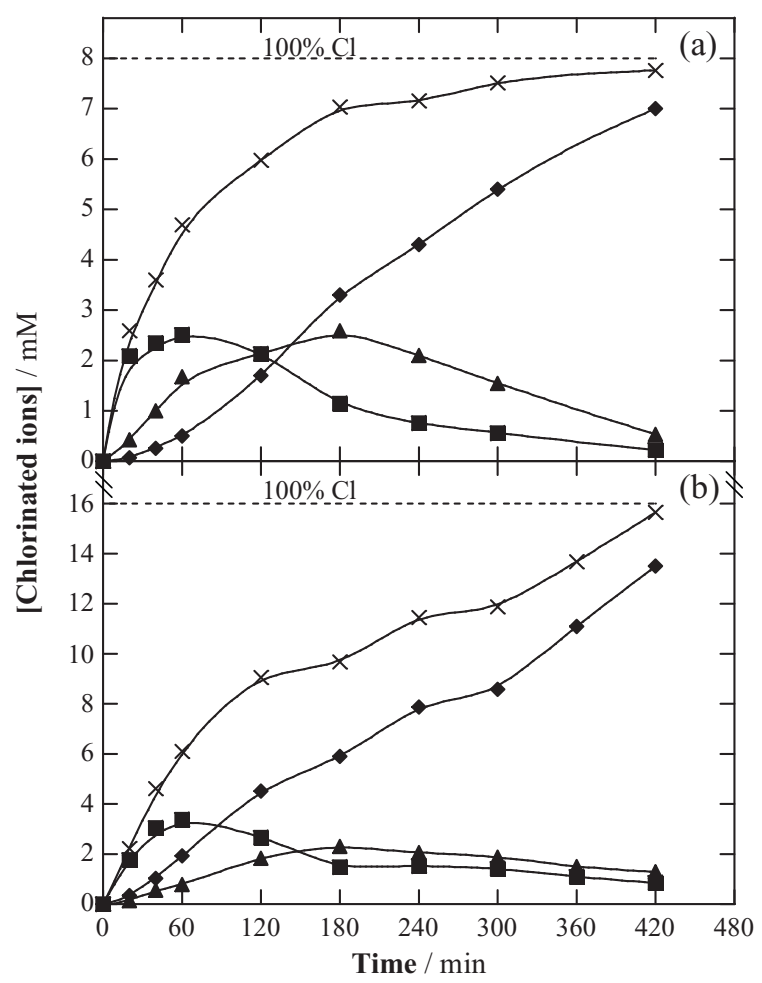

Fig. 9. Evolution of the concentration of the chlorinated ions released during the EF degradation of (a) $4 \mathrm{mM}$ DCA and (b) $4 \mathrm{mM}$ TCA in a BDD/ADE cell at $300 \mathrm{~mA}$. Ion: (घ) $\mathrm{Cl}^{-},(\boldsymbol{\Delta}) \mathrm{ClO}_{3}^{-},(\diamond) \mathrm{ClO}_{4}^{-}$and $(\times)$sum of the three ions.

by-products (see Fig. 6). Independent electrolyses performed for this acid showed that it is directly converted into $\mathrm{CO}_{2}$. Pathway $\mathrm{B}$ is similar to $\mathrm{A}$, but corresponds to the total oxidative dechlorination of DCA to oxalic acid. While the oxidation of most carboxylic acids mainly occurs at the anode surface, in the case of oxalic there exists a competition between the direct charge transfer and the hydroxyl radical-mediated oxidation [65-67]. In contrast, the $\mathrm{Fe}(\mathrm{III})$-carboxylate complexes tend to be more rapidly destroyed by ${ }^{\bullet} \mathrm{OH}$ in the bulk, but the $\mathrm{Fe}(\mathrm{III})$-oxalate complexes are not oxidized in the bulk and their reaction with $\operatorname{BDD}(\bullet \mathrm{OH})$ is also strongly inhibited, only being very slowly destroyed by direct charge transfer at the BDD surface $[8,68]$. Finally, pathway $C$ is a mixture of oxidative and reductive dechlorination that allows justifying the formation of acetic acid. Note that the mechanism for the electroreduction of an $\mathrm{R}-\mathrm{X}$ bond $(\mathrm{R}=$ hydrocarbon chain, $\mathrm{X}=\mathrm{F}, \mathrm{Cl}, \mathrm{Br}$, I) based on the Marcus theory explains the one-electron transfer leading to $\mathrm{RH}$ and $\mathrm{X}^{-}$[1]. Recently, Kapalka et al. [69] demonstrated that in $\mathrm{AO}$ with $\mathrm{BDD}$, acetic acid only reacts with $\mathrm{BDD}\left({ }^{\bullet} \mathrm{OH}\right)$, although its adsorption on the BDD surface causes the autoinhibition of the oxidation. However, in EF with BDD, acetic acid and its $\mathrm{Fe}(\mathrm{III})$ complexes can be totally removed thanks to the contribution of $\bullet \mathrm{OH}$ in the bulk. Therefore, acetic acid is oxidized to oxalic and formic acids which are directly transformed into $\mathrm{CO}_{2}$ [67].

Fig. 10(b) includes analogous sequences for TCA mineralization. Pathway $A^{\prime}$ is an oxidative dechlorination yielding dichloroacetic acid, which was confirmed to be directly oxidized to $\mathrm{CO}_{2}$. This is the main pathway for TCA. Pathway $\mathrm{B}^{\prime}$ leads to oxalic acid like in pathway B. Pathway $C^{\prime}$ involves the oxidative and reductive dechlorination steps like in pathway $C$ to yield acetic acid. Finally, pathway $\mathrm{D}^{\prime}$ is an alternative to $\mathrm{C}^{\prime}$ with only one reductive dechlorination step to generate chloroacetic acid, which is directly converted into $\mathrm{CO}_{2}$ as in Pathway A. 

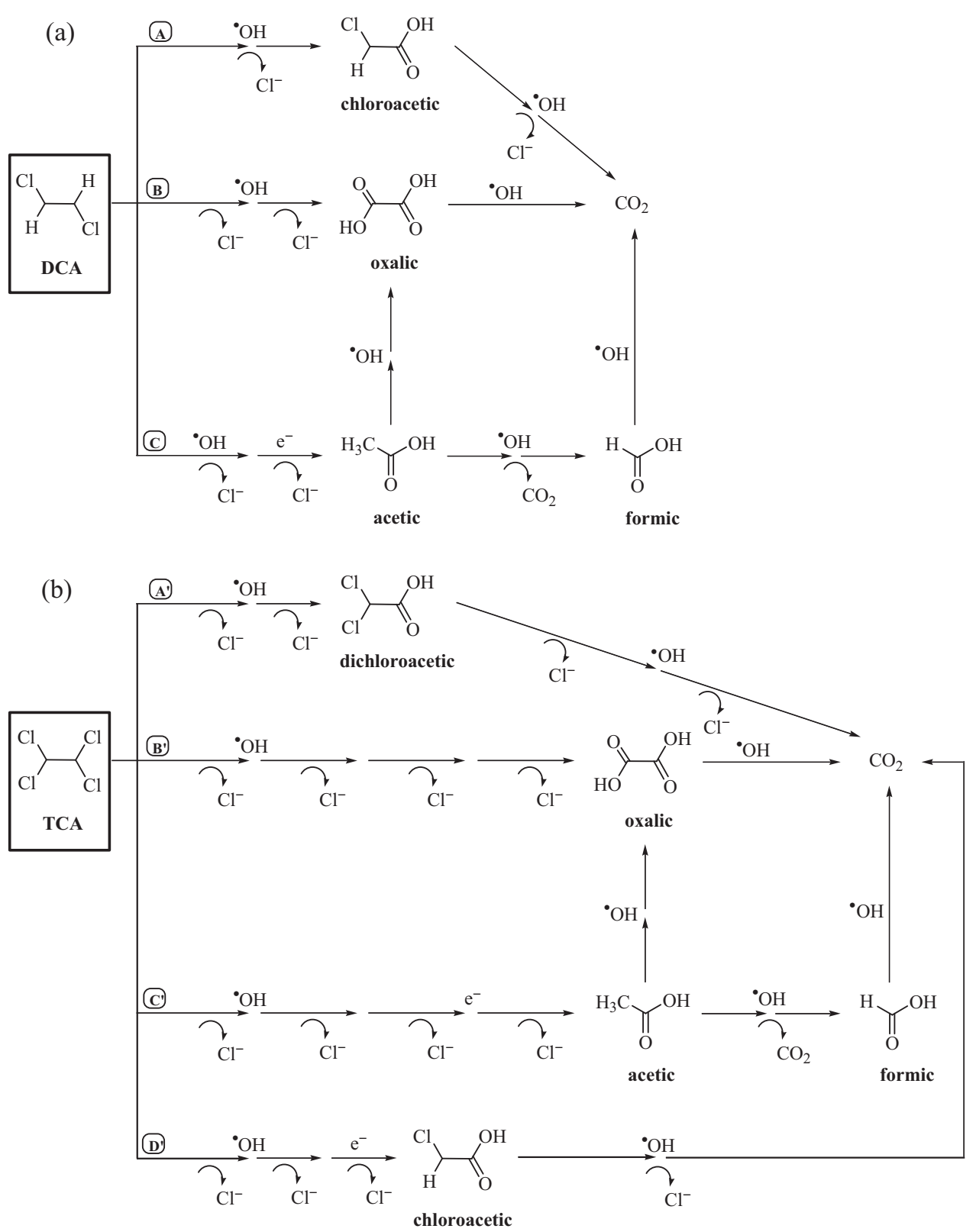

Fig. 10. Proposed reaction pathways for the mineralization of acidic aqueous solutions of: (a) DCA and (b) TCA by EAOPs.

\section{Conclusions}

It has been proven that $\mathrm{EF}$ with a BDD/ADE cell is a very effective technology for the decontamination of single and multicomponent DCA and TCA solutions. The determination of the time course of the main reaction by-products allowed clarifying the electrochemical degradation routes. Reductive (cathodic) and oxidative dechlorination steps contributed to the complete mineralization of DCA and TCA. However, as expected from the low electrocatalytic activity of the ADE to promote the electroreduction of the $\mathrm{C}-\mathrm{Cl}$ bond, the oxidative dechlorination mediated by ${ }^{\bullet} \mathrm{OH}$ and $\operatorname{BDD}\left(\bullet^{\bullet} \mathrm{OH}\right)$ had the pre-eminent role, yielding the quicker destruction of major hardly oxidizable by-products such as chloroacetic, dichloroacetic and acetic acids. A slightly lower mineralization rate was observed for DCA compared to TCA because of the harder oxidation of chloroacetic compared to dichloroacetic. The BDD surface and the $\operatorname{BDD}(\bullet \mathrm{OH})$ are then fundamental to achieve the complete destruction of the haloacetic acids, which otherwise can only be partially

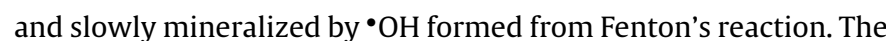
action of ${ }^{\bullet} \mathrm{OH}$ and $\mathrm{BDD}\left(\bullet^{\bullet} \mathrm{OH}\right)$ was also fundamental to convert the released $\mathrm{Cl}^{-}$into $\mathrm{ClO}_{3}{ }^{-}$and $\mathrm{ClO}_{4}{ }^{-}$, with production of more than $90 \%$ of the latter ion at high current.

\section{Acknowledgements}

Financial support from MICINN (Ministerio de Ciencia e Innovación, Spain) under project CTQ2010-16164/BQU, co-financed by FEDER funds, and from Università di Palermo is acknowledged.

\section{References}

[1] S. Rondinini, A. Vertova, Electroreduction of halogenated organic compounds, in: C. Comninellis, G. Chen (Eds.), Electrochemistry for the Environment, Springer Science + Business Media, New York, 2010, pp. 279-306.

[2] Chlorinated hydrocarbons, in: Ullmann's Encyclopedia of Industrial Chemistry, Wiley-VCH Verlag GmbH \& Co. KGaAed, 2002 (electronic edition). 
[3] European Commission, Identification of Priority Hazardous Substances under the Water Framework Directive, Directorate-General Environment, 2000.

[4] J.J. Pignatello, E. Oliveros, A. MacKay, Advanced oxidation processes for organic contaminant destruction based on the Fenton reaction and related chemistry, Crit. Rev. Environ. Sci. Technol. 36 (2006) 1-84.

[5] M. Klavarioti, D. Mantzavinos, D. Kassinos, Removal of residual pharmaceuticals from aqueous systems by advanced oxidation processes, Environ. Int. 35 (2009) 402-417.

[6] C.A. Martínez-Huitle, S. Ferro, Electrochemical oxidation of organic pollutants for the wastewater treatment: direct and indirect processes, Chem. Soc. Rev. 35 (2006) 1324-1340.

[7] A. Anglada, A. Urtiaga, I. Ortiz, Contributions of electrochemical oxidation to waste-water treatment: fundamentals and review of applications, J. Chem. Technol. Biotechnol. 84 (2009) 1747-1755.

[8] E. Brillas, I. Sirés, M.A. Oturan, Electro-Fenton process and related electrochemical technologies based on Fenton's reaction chemistry, Chem. Rev. 109 (2009) 6570-6631.

[9] M. Panizza, G. Cerisola, Direct and mediated anodic oxidation of organic pollutants, Chem. Rev. 109 (2009) 6541-6569.

[10] P. Cañizares, R. Paz, C. Sáez, M.A. Rodrigo, Electrochemical oxidation of alcohols and carboxylic acids with diamond anodes. A comparison with other advanced oxidation processes, Electrochim. Acta 53 (2008) 2144-2153.

[11] A. Beteta, P. Cañizares, M.A. Rodrigo, L. Rodríguez, C. Sáez, Treatment of door-manufacturing factories wastewaters using CDEO and other AOPs. A comparison, J. Hazard. Mater. 168 (2009) 358-363.

[12] P. Cañizares, R. Paz, C. Sáez, M.A. Rodrigo, Costs of the electrochemical oxidation of wastewaters: a comparison with ozonation and Fenton oxidation processes, J. Environ. Manage. 90 (2009) 410-420.

[13] C. Flox, J.A. Garrido, R.M. Rodríguez, F. Centellas, P.L. Cabot, C. Arias, E. Brillas, Degradation of 4,6-dinitro-o-cresol from water by anodic oxidation with a boron-doped diamond electrode, Electrochim. Acta 50 (2005) 3685-3692.

[14] A.M. Polcaro, A. Vacca, M. Mascia, S. Palmas, Oxidation at boron doped diamond electrodes: an effective method to mineralise triazines, Electrochim. Acta 50 (2005) 1841-1847.

[15] C. Flox, P.L. Cabot, F. Centellas, J.A. Garrido, R.M. Rodríguez, C. Arias, E. Brillas, Electrochemical combustion of herbicide mecoprop in aqueous medium using a flow reactor with a boron-doped diamond anode, Chemosphere 64 (2006) 892-902.

[16] M. Panizza, G. Cerisola, Biological and electrochemical oxidation of naphthalene sulfonates in a contaminated site leachate, J. Chem. Technol. Biotechnol. 81 (2006) 225-232.

[17] I. Sirés, E. Brillas, G. Cerisola, M. Panizza, Comparative depollution of mecoprop aqueous solutions by electrochemical incineration using $\mathrm{BDD}$ and $\mathrm{PbO}_{2}$ as high oxidation power anodes, J. Electroanal. Chem. 613 (2008) 151-159.

[18] L.S. Andrade, T.T. Tasso, D.L. da Silva, R.C. Rocha-Filho, N. Bocchi, S.R. Biaggio, On the performances of lead dioxide and boron-doped diamond electrodes in the anodic oxidation of simulated wastewater containing the Reactive Orange 16 dye, Electrochim. Acta 54 (2009) 2024-2030.

[19] C. Flox, C. Arias, E. Brillas, A. Savall, K. Groenen-Serrano, Electrochemical incineration of cresols: a comparative study between $\mathrm{PbO}_{2}$ and boron-doped diamond anodes, Chemosphere 74 (2009) 1340-1347.

[20] M. Hamza, R. Abdelhedi, E. Brillas, I. Sirés, Comparative electrochemical degradation of the triphenylmethane dye Methyl Violet with boron-doped diamond and Pt anodes, J. Electroanal. Chem. 627 (2009) 41-50.

[21] J. Rodriguez, M.A. Rodrigo, M. Panizza, G. Cerisola, Electrochemical oxidation of Acid Yellow 1 using diamond anode, J. Appl. Electrochem. 39 (2009) 2285-2289.

[22] S. Yoshihara, M. Murugananthan, Decomposition of various endocrinedisrupting chemicals at boron-doped diamond electrode, Electrochim. Acta 54 (2009) 2031-2038.

[23] J. Boudreau, D. Bejan, S. Li, N.J. Bunce, Competition between electrochemical advanced oxidation and electrochemical hypochlorination of sulfamethoxazole at a boron-doped diamond anode, Ind. Eng. Chem. Res. 49 (2010) 2537-2542

[24] M. Panizza, I. Sirés, G. Cerisola, Anodic oxidation of mecoprop herbicide at lead dioxide, J. Appl. Electrochem. 38 (2008) 923-929.

[25] I. Sirés, C.T.J. Low, C. Ponce-de-León, F.C. Walsh, The deposition of nanostructured $\beta-\mathrm{PbO}_{2}$ coatings from aqueous methanesulfonic acid for the electrochemical oxidation of organic pollutants, Electrochem. Commun. 12 (2010) 70-74.

[26] D. Pavlov, B. Monahov, Mechanism of the elementary electrochemical processes taking place during oxygen evolution on the lead dioxide electrode, J. Electrochem. Soc. 143 (1996) 3616-3629.

[27] A. Kapalka, G. Fóti, C. Comninellis, The importance of electrode material in environmental electrochemistry. Formation and reactivity of free hydroxyl radicals on boron-doped diamond electrodes, Electrochim. Acta 54 (2009) 2018-2023.

[28] A. Sánchez-Carretero, C. Sáez, P. Cañizares, M.A. Rodrigo, Electrochemical production of perchlorates using conductive diamond electrolyses, Chem. Eng. J. 166 (2011) 710-714.

[29] G.R. Agladze, G.S. Tsurtsumia, B.-I. Jung, J.-S. Kim, G. Gorelishvili, Comparative study of chemical and electrochemical Fenton treatment of organic pollutants in wastewater, J. Appl. Electrochem. 37 (2007) 985-990.

[30] S. Hammami, N. Oturan, N. Bellakhal, M. Dachraoui, M.A. Oturan, Oxidative degradation of direct Orange 61 by electro-Fenton process using a carbon felt electrode: application of the experimental design methodology, J. Electroanal. Chem. 610 (2007) 75-84.
[31] J.M. Peralta-Hernández, Y. Meas-Vong, F.J. Rodríguez, T.W. Chapman, M.I. Maldonado, L.A. Godínez, Comparison of hydrogen peroxide-based processes for treating dye-containing wastewater: decolorization and destruction of Orange II azo dye in dilute solution, Dyes Pigments 76 (2008) 656-662.

[32] S. Figueroa, L. Vázquez, A. Alvarez-Gallegos, Decolorizing textile wastewater with Fenton's reagent electrogenerated with a solar photovoltaic cell, Water Res. 43 (2009) 283-294.

[33] A. Özcan, M.A. Oturan, N. Oturan, Y. Şahin, Removal of Acid Orange 7 from water by electrochemically generated Fenton's reagent, J. Hazard. Mater. 163 (2009) 1213-1220.

[34] M. Panizza, G. Cerisola, Electro-Fenton degradation of dyes, Water Res. 43 (2009) 339-344.

[35] E. Rosales, M. Pazos, M.A. Longo, M.A. Sanromán, Electro-Fenton decoloration of dyes in a continuous reactor: a promising technology in colored wastewater treatment, Chem. Eng. J. 155 (2009) 62-67.

[36] A.R. Khataee, V. Vatanpour, A.R. Amani Ghadim, Decolorization of C.I. Acid Blue 9 solution by UV/Nano-TiO 2 , Fenton, Fenton-like, electro-Fenton and electrocoagulation processes: a comparative study, J. Hazard Mater. 161 (2010) 1225-1233.

[37] N. Oturan, M.A. Oturan, Degradation of three pesticides used in viticulture by electrogenerated Fenton's reagent, Agron. Sustain. Dev. 25 (2005) 267-270.

[38] A. Kesraoui Abdessalem, N. Oturan, N. Bellakhal, M. Dachraoui, M.A. Oturan, Experimental design methodology applied to electro-Fenton treatment for degradation of herbicide chlortoluron, Appl. Catal. B-Environ. 78 (2007) 334-341.

[39] I. Sirés, F. Centellas, J.A. Garrido, R.M. Rodríguez, C. Arias, P.L. Cabot, E. Brillas, Mineralization of clofibric acid by electrochemical advanced oxidation processes using a boron-doped diamond anode and $\mathrm{Fe}^{2+}$ and UVA light as catalysts, Appl. Catal. B-Environ. 72 (2007) 373-381.

[40] M. Skoumal, R.M. Rodríguez, P.L. Cabot, F. Centellas, J.A. Garrido, C. Arias, E. Brillas, Electro-Fenton, UVA photoelectro-Fenton and solar photoelectro-Fenton degradation of the drug ibuprofen in acid aqueous medium using platinum and boron-doped diamond anodes, Electrochim. Acta 54 (2009) 20772085.

[41] A. Dirany, I. Sirés, N. Oturan, M.A. Oturan, Electrochemical abatement of the antibiotic sulfamethoxazole from water, Chemosphere 81 (2010) 594-602.

[42] I. Sirés, N. Oturan, M.A. Oturan, Electrochemical degradation of $\beta$-blockers. Studies on single and multicomponent synthetic aqueous solutions, Water Res. 44 (2010) 3109-3120.

[43] E. Isarain-Chávez, P.L. Cabot, F. Centellas, R.M. Rodríguez, C. Arias, J.A. Garrido, E. Brillas, Electro-Fenton and photoelectro-Fenton degradations of the drug betablocker propranolol using a Pt anode: identification and evolution of oxidation products, J. Hazard. Mater. 185 (2011) 1228-1235.

[44] E. Brillas, M.A. Baños, S. Camps, C. Arias, P.L. Cabot, J.A. Garrido, R.M. Rodríguez, Catalytic effect of $\mathrm{Fe}^{2+}, \mathrm{Cu}^{2+}$ and UVA light on the electrochemical degradation of nitrobenzene using an oxygen-diffusion cathode, New J. Chem. 28 (2004) 314-322.

[45] D. Montanaro, E. Petrucci, C. Merli, Anodic, cathodic and combined treatments for the electrochemical oxidation of an effluent from the flame retardant industry, J. Appl. Electrochem. 38 (2008) 947-954.

[46] M. Yoshida, B.D. Lee, M. Hosomi, Decomposition of aqueous tetrachloroethylene by Fenton oxidation treatment, Water Sci. Technol. 42 (2000) 203-208.

[47] Z. Qiang, W. Ben, C.-P. Huang, Fenton process for degradation of selected chlorinated aliphatic hydrocarbons exemplified by trichloroethylene, 1,1dichloroethylene and chloroform, Front. Environ. Sci. Eng. China 2 (2008) 397-407.

[48] M. Vilve, S. Vilhunen, M. Vepsäläinen, T.A. Kurniawan, N. Lehtonen, H. Isomäki, M. Sillanpää, Degradation of 1,2-dichloroethane from wash water of ionexchange resin Fenton's oxidation, Environ. Sci. Pollut. Res. 17 (2010) 875-884.

[49] P. Pichat, L. Cermenati, A. Albini, D. Mas, H. Delprat, C. Guillard, Degradation processes of organic compounds over UV-irradiated $\mathrm{TiO}_{2}$. Effect of ozone, Res. Chem. Intermed. 26 (2000) 161-170.

[50] S. Malato Rodríguez, J. Blanco Gálvez, M.I. Maldonado Rubio, P. Fernández Ibáñez, W. Gernjak, I. Oller Alberola, Treatment of chlorinated solvents by $\mathrm{TiO}_{2}$ photocatalysis and photo-Fenton: influence of operating conditions in a solar pilot plant, Chemosphere 58 (2005) 391-398.

[51] R.F.P. Nogueira, M.R.A. Silva, A.G. Trovo, Influence of the iron source on the solar photo-Fenton degradation of different classes of organic compounds, Solar Energy 79 (2005) 384-392.

[52] W.-S. Lee, J.-E. Kim, H.-S. Kim, C.-Y. Ahn, H.-M. Oh, Serial degradation of perchloroethylene by Delftia sp. N6 after dechlorination using Fenton's reagent, J. Microbiol. Biotechnol. 16 (2006) 1734-1739.

[53] J. Marugán, J. Aguado, W. Gernjak, S. Malato, Solar photocatalytic degradation of dichloroacetic acid with silica-supported titania at pilot plant scale, Catal. Today 129 (2007) 59-68.

[54] O. Scialdone, C. Guarisco, A. Galia, R. Herbois, Electroreduction of aliphatic chlorides at silver cathodes in water, J. Electroanal. Chem. 641 (2010) 14-22.

[55] R. Bejankiwar, J.A. Lalman, R. Seth, N. Biswas, Electrochemical degradation of 1,2-dichloroethane (DCA) in a synthetic groundwater medium using stainlesssteel electrodes, Water Res. 39 (2005) 4715-4724.

[56] O. Scialdone, A. Galia, G. Filardo, Electrochemical incineration of 1,2dichloroethane: effect of the electrode material, Electrochim. Acta 53 (2008) $7220-7225$.

[57] O. Scialdone, A. Galia, L. Gurreri, S. Randazzo, Electrochemical abatement of chloroethanes in water: reduction, oxidation and combined processes, Electrochim. Acta 55 (2010) 701-708. 
[58] I. Sirés, P.L. Cabot, F. Centellas, J.A. Garrido, R.M. Rodríguez, C. Arias, E. Brillas, Electrochemical degradation of clofibric acid in water by anodic oxidation. Comparative study with platinum and boron-doped diamond electrodes, Electrochim. Acta 52 (2006) 75-85.

[59] S. Ferro, A. De Battisti, I. Duo, C. Comninellis, W. Haenni, A. Perret, Chlorine evolution at highly boron-doped diamond electrodes, J. Electrochem. Soc. 147 (2000) 2614-2619.

[60] M. Murata, T.A. Ivandini, M. Shibata, S. Nomura, A. Fujishima, Y. Einaga, Electrochemical detection of free chlorine at high boron-doped diamond electrodes, J. Electroanal. Chem. 612 (2008) 29-36.

[61] A.M. Polcaro, A. Vacca, M. Mascia, S. Palmas, J. Rodriguez Ruiz, Electrochemical treatment of waters with BDD anodes: kinetics of the reactions involving chlorides, J. Appl. Electrochem. 39 (2009) 2083-2092.

[62] M. Mascia, A. Vacca, A.M. Polcaro, S. Palmas, J. Rodriguez Ruiz, A. Da Pozzo, Electrochemical treatment of phenolic waters in presence of chloride with boron-doped diamond (BDD) anodes: experimental study and mathematical model, J. Hazard. Mater. 174 (2010) 314-322.

[63] M.E.H. Bergmann, J. Rollin, T. Iourtchouk, The occurrence of perchlorate during drinking water electrolysis using BDD anodes, Electrochim. Acta 54 (2009) 2102-2107.
[64] L.J.J. Janssen, P.D.L. Heyden, Mechanism of anodic oxidation of chlorate to perchlorate on platinum electrodes, J. Appl. Electrochem. 25 (1995) 126-136.

[65] O. Scialdone, A. Galia, C. Guarisco, S. Randazzo, G. Filardo, Electrochemica incineration of oxalic acid at boron doped diamond anodes: role of operative parameters, Electrochim. Acta 53 (2008) 2095-2108

[66] O. Scialdone, S. Randazzo, A. Galia, G. Silvestri, Electrochemical oxidation of organics in water: role of operative parameters in the absence and in the presence of $\mathrm{NaCl}$, Water Res. 43 (2009) 2260-2272.

[67] S. Ferro, C.A. Martínez-Huitle, A. De Battisti, Electroxidation of oxalic acid at different electrode materials, J. Appl. Electrochem. 40 (2010) 17791787.

[68] M.A. Oturan, M. Pimentel, N. Oturan, I. Sirés, Reaction sequence for the mineralization of the short-chain carboxylic acids usually formed upon cleavage of aromatics during electrochemical Fenton treatment, Electrochim. Acta 54 (2008) 173-182.

[69] A. Kapalka, G. Fóti, C. Comninellis, Investigation of the anodic oxidation of acetic acid on boron-doped diamond electrodes, J. Electrochem. Soc. 155 (2008) E27-E32. 